\title{
Sobre mitos antiguos y héroes modernos: Una relectura de La Historia Interminable a partir de EI héroe de las mil caras'
}

\author{
On Old Myths and Modern Heroes: a Rereading of Michael Ende's The \\ Neverending Story from Joseph Campbell's The Hero with a Thousand
}

\author{
MARÍA DEL CARMEN JIMÉNEZ ARIZA \\ CEP Emilia Olivares \\ España \\ carmen.ariza@wanadoo.es
}

(Recibido O9-IO-2OI2; aceptado o8-O7-2013)

Resumen. La "crítica mítica" es una corriente de análisis que, desde una perspectiva antropológica, estudia los mitos y símbolos presentes en la literatura y en los cuentos populares. Joseph Campbell, uno de los máximos exponentes de este movimiento, explica los grandes mitos a partir del concepto junguiano de inconsciente colectivo, entendido éste como el sustrato simbólico de carácter ancestral que se constituye en influencia universal y es recurrente en todas las civilizaciones. La Historia interminable, obra mundialmente conocida de Michael Ende, puede ser releída bajo el prisma de las teorías de Campbell, en un intento de corroborar que los arquetipos siguen presentes en las manifestaciones culturales de la humanidad.

Palabras clave: Libros infantiles; literatura de ficción; inconsciente colectivo; leyenda; mitología.
Abstract. "Mythic criticism" is a trend of analysis that, from an anthropological perspective, studies the myths and symbols in literature and folktales. Joseph Campbell, is one of the leading exponents of this movement, and explains the great myths through the Jungian concept of the collective unconscious, this being understood as the symbolic substrate of ancestral character constituted under the universal influence and that is recurrent in all the civilizations. The Neverending Story, a world renowned work by Michael Ende, can be thus interpreted through the prism of Campbell's theories, in an attempt to corroborate that the archetypes are still present in the cultural manifestations of humanity.

Key words: Children's books; fiction; collective unconscious; legends; mythology.

\footnotetext{
I Para citar este artículo: Jiménez Ariza, $\mathrm{M}^{\mathrm{a}}$ del Carmen (2OI3). Sobre mitos antiguos y héroes modernos: Una relectura de $L a$ Historia Interminable a partir de El héroe de las mil caras. Alabe 8. [www.revistaalabe.com]
} 


\section{Cuando cifras y figuras \\ ya no sean clave de todas las criaturas, cuando quienes cantan y besan sepan más que los hombres de honda ciencia, cuando el mundo regrese al mundo y a la vida en libertad, cuando se unan luz y sombra en verdadera claridad, y en cuentos y poesías se descubran las verdaderas historias del mundo, entonces, ante una palabra secreta volando se irá todo el ser alterado.}

Novalis $^{2}$

\section{I - A modo de introducción: ¿un libro de fantasía, sin más?}

En el género literario de la literatura infantil, la fantasía se erige, posiblemente, en el subgénero más conocido y apreciado por los lectores. Habitualmente, las obras de fantasía suelen presentar lo que podemos llamar un "mundo paralelo", independiente pero relacionado con el mundo real, en el cual habitan seres imaginarios que suelen regirse por otras leyes vitales y temporales.

Además, es usual encontrar en muchas de estas obras la doble finalidad horaciana de docere et delectare, ya que, por una parte los mundos fantásticos presentan una serie de similitudes y diferencias con nuestras sociedades que dan pie a observar el mundo real desde otras perspectivas y, por otra, ayudan a fomentar la imaginación. Es frecuente también que los niños protagonistas posean autonomía o cierta independencia: se aparten de la protección paterna, les falte alguno de sus progenitores... lo que posibilita la exclusión de ciertas dosis de pragmatismo adulto que limitarían los peligros y riesgos inherentes a la aventura. Así, el recurso de la fantasía es útil para solucionar problemas reales de forma imaginativa, ofrecer una vía de escape a una existencia anodina o desgraciada, enfrentar al protagonista a situaciones problemáticas que requieren echar mano del valor, la astucia o la inteligencia para su resolución. De igual forma, la fantasía puede ser un eficaz vehículo para la enseñanza de la moral y la ética, puesto que el viaje al mundo fantástico también implica cruzar una frontera social. Llegados al mundo imaginario, los aventureros deben conocer las leyes que lo rigen, comprender la idiosincrasia de sus habitantes, luchar contra el mal en alguna de sus facetas, etc. Esto posibilita que, antes de volver al mundo real, el protagonista sufra una metamorfosis: ha adquirido otros valores o virtudes, ha

\footnotetext{
${ }^{2}$ En Ende, M. (I996). Pensamientos de un indígena centroeuropeo, Carpeta de apuntes. Obtenido el i5 de junio de 2OI2 desde: http://ende.blogcindario.com/2009/O4/oor33-pensamientos-de-un-indigena-centroeuropeo.html
} 
conocido la forma de actuar de los adultos, ha tomado decisiones de envergadura. En este sentido, podemos afirmar con Pérez Valverde (2002: I68) que la mayoría de las fantasías son Bildungsroman, es decir, novelas de educación ${ }^{3}$.

Por lo que respecta a la recepción crítica del género ${ }^{4}$, los estudios se han abordado "desde una doble perspectiva: de una parte, como fenómeno que hunde sus raíces en el inconsciente, los arquetipos y la tradición mítica; de otra, como producción cultural propia de una época e ideología, y como tal portadora de valores" (Pérez Valverde, 20IO: 297). La primera de las citadas es una corriente de análisis denominada "crítica mítica" que, desde una perspectiva antropológica, estudia los mitos y símbolos presentes en la literatura y en los cuentos populares. Uno de los máximos exponentes de este movimiento es Joseph Campbell, que explica los grandes mitos a partir del concepto junguiano de inconsciente colectivo, entendido éste como el sustrato simbólico de carácter ancestral que se constituye en influencia universal y es recurrente en todas las civilizaciones. Estos mitos, estrechamente relacionados con la psique humana, son una manifestación cultural de la necesidad universal de hallar una explicación a la realidad global. En consonancia, los motivos que hallamos en los cuentos tradicionales componen un lenguaje de imágenes que contiene valores universalmente aceptados. En Campbell, la figura del héroe es el mito primordial: los ciclos por los que atraviesa (partida, iniciación, apoteosis y regreso) son comunes a todas las culturas y reaparecerán a lo largo del tiempo en cuentos, mitos y leyendas hasta llegar a la mismísima actualidad. Así, afirma (i972: 27):

Como veremos, la aventura del héroe, ya sea presentada con las vastas, casi oceánicas imágenes del Oriente, o en las vigorosas narraciones de los griegos y romanos, o en las majestuosas leyendas de la Biblia, normalmente sigue el modelo de la unidad nuclear arriba descrita; una separación del mundo, la penetración a alguna fuente de poder, y un regreso a la vida para vivirla con más sentido (Sidartha Gautama, Prometeo, Jasón, Eneas o Moisés).

Nos proponemos en este trabajo analizar la obra de Michael Ende bajo el prisma de las teorías de Campbell, en un intento de corroborar que, también en el imaginario del autor alemán (I972: 25), "los arquetipos que han de ser descubiertos y asimilados son precisamente aquellos que han inspirado, a través de los anales de la cultura humana, las imágenes básicas del ritual, de la mitología y de la visión.”

\footnotetext{
3 Michael Ende denostará este tipo de literatura: "Estoy en contra del escritor como un maestro que tiene que enseñar..., de toda esta literatura didáctica que pretende siempre enseñar algo a los lectores. Creo que el sentido del arte, de todas las artes, es hacer volver al lector a su vida cotidiana con algo cambiado en la conciencia. Y este cambio se da por la imaginación”. Vid. Pereda, R. M. (I982). La imaginación cambia la conciencia del lector. El País, 9 de Junio de 1982.

${ }^{4}$ Habrá que esperar al Romanticismo para encontrar una aproximación psicológica al estudio de la creación literaria. Escritores como Coleridge, Shelley o Blake potencian el papel de la imaginación en el texto, que tiene lugar con la irrupción del inconsciente a través del elemento onírico. Este pensamiento enlazará con las ideas psicoanalíticas de Freud, Jung y Adler, de incuestionable influencia en la hermenéutica literaria.
} 


\section{2 - El imaginario poético de Michael Ende}

Las discusiones diacrónicas sobre el discurso estético se han alineado, históricamente, en torno a dos conceptos: la mimesis, entendida como una representación de la Naturaleza, o la fantasía, defendida por San Agustín como forma de conocimiento de la creación divina. Desde ellas, diversas corrientes han enfatizado uno u otro matiz:

Así, la estética del "arte por el arte”, mantenida por Kant, Schiller, Hegel... se refiere a la autonomía artística, que no se justifica por fines didácticos o morales, sino en función de su capacidad para desvelar fantasías o misterios. En estas propuestas subyace el escepticismo hacia el auge de lo científico: si algo puede aportar la literatura a la humanidad es belleza.

Otra corriente concibe la literatura como ficción: es un ideal superior a la imitación, pues limpia el mundo imperfecto y nos hace disfrutar la realidad en un plano más profundo y elevado (Poe. Baudelaire, Young, Home). Sin embargo, las formulaciones neoaristotélicas (Rimbaud) propugnaron una concepción de la literatura como vía de conocimiento de las profundidades psicológicas del ser, es decir: la literatura como forma de conocimiento.

El Romanticismo, por otra parte, se decanta por la concepción de la Literatura como evasión: una vía idónea para escapar del mundo cotidiano y crear uno nuevo, postura que ya recogían los clásicos (Homero, Virgilio, Eurípides) y la poesía bucólica de las épocas helenística y renacentista.

Finalmente, encontramos la creencia en una Literatura como protesta, o literatura comprometida: Sartre aboga por el escritor que asume su papel como desvelador de los comportamientos humanos para transformarlos. La literatura pasa así de héxis (literatura burguesa de mero consumo) a praxis (agente de cambio revolucionario).

En su Carpeta de apuntes, un valiosísimo documento para analizar la obra de Ende (2002: s. p.), el autor se confiesa deudor del Romanticismo alemán, y dice formar parte de una especie de "casta", los denominados "indígenas centroeuropeos". De sus palabras, es fácil adivinar las corrientes literarias que han influido en sus creaciones:

Hasta entonces, nosotros proseguiremos a nuestra manera el combate. Nuestra religión se llama poesía. Creemos que la poesía es una necesidad vital, elemental del hombre, a veces más vital que comer y beber (...). La poesía es la capacidad creativa del hombre para sentirse y reconocerse siempre de una forma nueva en el mundo, y para sentir y reconocer al mundo en sí mismo. Por eso, toda poesía es, por esencia, antropomórfica o dejará de ser poesía. Y, precisamente por eso, toda poesía tiene afinidad con lo infantil. Nosotros los indígenas decimos incluso: es lo que hay en el hombre de eternamente infantil. 
Si nos retrotraemos al contexto existencial del que bebe el autor, asistiremos a una corriente intelectual en la que el espíritu materialista imperante crea el efecto que Max Weber denominó de "desencantamiento del mundo", un estado de consciencia en el cual todos los mitos y las concepciones mágico-religiosas han sido sustituidas por una visión positivista del mundo, basada en la suposición de que todo lo que existe debe ser comprendido, comprobado y refutado por el análisis científico. Desde esta óptica, la poesía es mera estética y, por tanto, inútil. Muy al contrario, Ende (I996) sostiene que una buena poesía transforma al mundo, y ello en un contexto creativo en el que la literatura elige al nihilismo o la ironía como génesis creadora:

El escritor estaba por así decir ante un imaginario tribunal de justicia, ya fuese como fiscal del Estado o como defensor y abogado, y su libro, su pieza teatral, su poema tenían que probar algo: una culpa, un hecho social, un desarrollo histórico. Esa prueba era después examinada con vistas a su carácter conclusivo, era refutada, se presentaban pruebas en contra, que eran refutadas a su vez, en resumen, se veía toda la literatura desde una única perspectiva, la del argumento. Esto valía también para el libro infantil y hasta para los libros ilustrados. [...]. Lo que yo ataco decididamente es ese rabioso dogmatismo que propugnaban y siguen propugnando los representantes de tal literatura. [...].La Odisea y la Ilíada, Las mil y una noches, Don Quijote de La Mancha, nuestros cuentos populares, el Fausto, las grandes novelas de Balzac o Dostoievski, los dramas y las comedias de Shakespeare: todas ellas ni prueban ni refutan nada. Son algo. Presentan mundos pero no explican el mundo.

Ese "indigenismo" recalcitrante que instaura en Ende un pensamiento divergente será, posiblemente, el propulsor de una necesidad existencial que lo acercará al surrealismo que conociera a través de su padre, el pintor Edgar Ende (con él descubre a Goya y a Chagall, y de cuyas imágenes pictóricas parece nutrirse su obra), y que más tarde lo llevaría a la literatura fantástica de la mano de sus admirados Jorge Luís Borges y Kafka, claras influencias de su literatura "adulta” (El espejo en el espejo, Elponche de los deseos), así como J. R. R. Tolkien lo será de su literatura infantil y juvenil. Como confeso deudor de Borges, además, toma ideas y recursos dialécticos, y la afición por recrear escenarios laberínticos u oníricos. En lo literario, decíamos, se confiesa heredero del romanticismo alemán y, particularmente, del poeta Novalis, presente tanto en su interpretación mística y panteísta del universo, como al afirmar que no busca verdades objetivas sino sabiduría, que su religión es la poesía y que poesía "es la capacidad creativa que tiene el hombre de vivirse y de reconocerse a sí mismo una y otra vez en el mundo y al mundo en sí mismo", y que “por eso toda poesía o es, en su esencia, antropomórfica, o dejará de ser poesía”.

Desde estas concepciones Ende realiza en su obra una contundente crítica de la sociedad. Para él, las grandes amenazas de la civilización son las guerras, los conflictos sociales o la pobreza ${ }^{5}$, todo ello debido a la pérdida de sentido de la vida y expresado magistralmente en La Historia Interminable con el dominio de la Nada.

\footnotetext{
5 Precisamente, sus Pensamientos de un indígena centroeuropeo vienen precedidos por una cita del Woyzeck de Büchner, que será un referente en el pensamiento europeo de entreguerras: el pícaro que asiste a un mundo en descomposición y echa mano del sentido del humor para sobrevivir a la hecatombe...
} 
El recurso a la fantasía, por tanto, será para él una forma de expresar simbólicamente los sentimientos del alma, algo que ya fue utilizado por los pueblos primitivos en los que, por otra parte, tanto se interesó. Así, el sentido de la existencia, el valor de la libertad, las paradojas espacio-temporales que constituyen el entramado de sus textos, suponen el redescubrimiento de otra realidad oculta que puede coexistir con la cotidiana y mejorarla, como él mismo explica (2002: s. p.): "Un reino mágico de imaginación y fantasía a la cual es preciso viajar para tornarse vidente. Entonces se puede volver a la realidad exterior con una nueva conciencia transformada, y transformar esa realidad o por lo menos, vivirla de manera diferente". Esta primacía del sentimiento y la imaginación que advertimos en Ende, ese "Sturm und Drang" impetuoso que exalta la intuición creadora y se rebela contra una visión convencional y pragmática del mundo es, sin duda, fiel reflejo de la estética romántica que tanto influyó en el pensamiento y obra del autor alemán.

Por eso, en el Bastián de su Historia Interminable está simbolizada la vida interior del hombre, la creación de una nueva subjetividad que busca lo que el gran romántico alemán, Novalis, había buscado ya antes: "den geheimnisvollen Wegnachinnen", el camino misterioso hacia el interior, que en realidad es la senda que lleva a la libertad del individuo.

Pues como existencialista por herencia y vocación, la fascinación de Michael Ende por los enigmas de la libertad cobra forma en La Historia Interminable: se evidencia, pongamos por caso, cuando Atreyu debe cruzar las tres puertas para llegar al Oráculo del Sur y cuando Bastián entra en el castillo cuyas puertas conducen a cualquier lado. Las respuestas de ambos, tan próximas y tan lejanas entre sí, ponen de manifiesto la vivencia misma de la libertad. La puerta es el símbolo predilecto de Ende para representarla, porque toda puerta pide ser abierta y a la vez encierra algo misterioso que incita a la reflexión y a la libertad personal de optar por ese descubrimiento. De esta forma, la libertad adquiere toda su significación en la expresión "haz lo que quieras", afirmación de un concepto de libertad que Bastián tiene que ir aprendiendo porque es difícil que, en puridad, uno sepa realmente qué es lo que quiere.

Esto da sentido, además, a otra cualidad de la obra: la reflexión sobre el lenguaje y la importancia que da a las palabras. Veremos cómo "El Gran Lenguaje” se erige en el nexo que une a la amalgama de habitantes de Fantasía. Además, Ende llena sus páginas de juegos de palabras y de enigmas en los que las propias palabras se convierten en reflexión de sí mismas y en la llave que descubre el enigma. Los personajes tienen nombres que se caracterizan por su simbolismo, su sonoridad casi onomatopéyica, o por un cierto tinte misterioso o esotérico. Esa cuidada elaboración posiblemente sea debida a su convicción de que "dar un nombre - no sólo una designación, sino su verdadero nombre-a las cosas y a los seres todavía anónimos es la más íntimamente humana de todas las facultades humanas". Y a la postre, veremos que esa acción será el acto supremo de salvación que un humano le conceda al reino imaginario de Fantasía. 
Finalmente, desde la perspectiva de la semántica del texto, la metaficción constituye uno de los procedimientos fundamentales de la obra; ofrece varias lecturas posibles y propone una ficción para reflexionar acerca de la naturaleza y el alcance de la ficción misma, y esto se palpa desde la sobrecubierta ilustrada con el Ouroboros: las dos serpientes que se muerden la cola en una alegoría de la eternidad son, en sí mismas -parece querer decirnos Ende-, una historia interminable.

\section{3 -Novedades de La historia interminable respecto a otros libros del género}

Posiblemente, la mayor novedad que presenta este relato respecto a otras obras fantásticas de la Literatura sea que es un libro que se contiene a sí mismo: en la propia trama del relato aparece el libro, haciendo que el argumento se constituya en una historia contada dentro de la historia; es decir, la materia alquímica de la novela, su fórmula secreta, es haber sabido convertir el propio libro en un espacio mágico, en una especie de sortilegio. Pues el gran protagonista de La Historia interminable es el propio libro, a semejanza de aquella paradoja que creara Julio Cortázar sobre el hombre que lee un relato y se percata de que su propio asesinato está inserto en la trama del texto. E incluso recordando aquello que dijera Borges (r998: 79): “¿Por qué nos inquieta que Don Quijote sea lector del Quijote, y Hamlet, espectador de Hamlet?”. ¿Pueden cuestionar de qué lado está la ficción y hacer creer al lector que los humanos son los seres ficticios?

De esta forma, el autor juega con el lector del mismo modo que el libro que lee el personaje juega con él: Bastián pasa de ser lector a convertirse en protagonista de las aventuras que ocurren en el libro. Es una historia, además, que en sí misma contiene otras muchas que el narrador menciona, pero no desarrolla, como si pretendiera dejar una puerta abierta a futuras narraciones. Al mismo tiempo, este muestrario de historias que se bifurcan aporta un nuevo significado al título de la novela: la historia es interminable porque, a su través, van apareciendo nuevas puertas para abrir y narrar otros episodios, de ahí su carácter infinito.

La Historia Interminable, pues, se asemeja a una gran construcción arquitectónica que puede leerse desde dos perspectivas: si se contempla desde fuera, sólo veremos un magnífico relato fantástico de aventuras. Si, además, nos adentramos en su estructura, hallaremos los cimientos de una inmensa catedral barroca erigidos sobre innumerables alusiones al humanismo europeo y a la mitología clásica. Y a poco que excavemos, ora aparecen referencias a religiones orientales, ora percibimos una suerte de sincretismo revelado en mosaicos de evidencias inequívocamente cristianas (nótese, por ejemplo. en la simbología de la Torre de Marfil, advocación eminentemente mariana). 
A esto debe agregarse una lista de recursos tremendamente originales: las reminiscencias góticas de su letra capital; la peculiar estructuración de capítulos que empiezan por una palabra cuya primera letra sigue la secuencia alfabética, en orden ascendente (¿alusión al apocalíptico Alfa y Omega?); la yuxtaposición de los dos mundos, que se reflejan por el cambio de color en las letras impresas (rojas para el real, y verdes para el imaginario); el ingenio con el que una y otra vez se reafirma en la "eternidad" de su historia, pues, como ya dijimos, antes de dejar atrás algún personaje que no aparecerá de nuevo, lo sitúa en una nueva narración que dejará inconclusa, afirmando -como ya dijera Kiplingque "esa es otra historia y deberá ser contada en otra ocasión”.

En definitiva, nos hallamos frente a una gran novela que se puede disfrutar de, al menos, dos maneras posibles y no excluyentes entre sí: leyéndola como una fantástica historia infantil, dejándonos llevar hasta los límites insondables de nuestra propia imaginación, o bien como una obra plagada de significados ocultos que, de forma simbólica, encierra profundos conocimientos míticos, literarios y religiosos.

Es nuestro propósito adentrarnos en la densa urdimbre de esos significados para tratar de desentrañar ese universo plagado de símbolos. Veremos que, en realidad, la obra se inserta tanto en la tradición de los viajes de aventuras y posee paralelismos con Tolkien, Carroll e incluso Dante, como en el sustrato común y arquetípico de los relatos míticos enunciado por Campbell. Para ello empezaremos por el principio:

\section{4-El argumento del libro}

Para centrarnos en las claves del relato, creemos conveniente refrescar el argumento del libro a modo de sinopsis comentada:

La Historia Interminable marca un hito en la literatura infantil y juvenil al contar las peripecias de un antihéroe: Bastián, el protagonista, es un niño con diversos problemas emocionales y de autoestima; la orfandad materna y la indiferencia paterna, la realidad escolar dura e inmisericorde, es el punto de partida de la aventura. Una anómala pasión por la lectura le incita a robar un atrayente libro descubierto en la librería del viejo Karl Kurt Koreander, y conforme se va adentrando en sus páginas, se da cuenta de que es invitado a participar en la aventura de salvar el reino de Fantasía, que perece lentamente víctima de una extraña enfermedad: la Nada se está adueñando del mundo imaginario, cebándose, además, en el mismísimo corazón que hace latir a ese mundo, que es su Emperatriz Infantil.

Un mensajero real partirá a la búsqueda del héroe que pueda salvar al reino. Atreyu, "el hijo de todos” (¿alusión bíblica de nuevo, evocando el nombre primigenio 
de Adán?) será el elegido y, protegido por Auryn, un medallón mágico que le conferirá poderes especiales, partirá a la búsqueda de la salvación. A tal efecto afirma el mensajero:

Dondequiera que pueda estar la posibilidad de salvación... una cosa es segura: su búsqueda requiere un explorador capaz de encontrar su camino en lo intransitable y de no retroceder ante ningún peligro ni ningún esfuerzo; en una palabra: un héroe. Y la Emperatriz Infantil me ha dicho el nombre de ese héroe, al que confía su destino y el nuestro: se llama Atreyu y vive en el Mar de Hierba, detrás de los Montes de Plata. Yo le entregaré a ÁURYN y lo enviaré a la Gran Búsqueda. (Ende, I999: 28)

Sin conocer exactamente su cometido, Atreyu emprende el viaje; será la sabiduría de la ancianidad, en la forma de la tortuga Vetusta Morla, quien le descubra el remedio para vencer el mal que aqueja al reino: la Emperatriz necesita un nuevo nombre. Éste será el primer guiño que la historia hace al lector, pues el nombre, en tanto que identidad, sólo puede ponerlo un ser humano.

Y ello debido a que el tránsito entre los dos mundos es posible; así lo explica la Emperatriz Infantil en una clara alusión al camino interior, a ese ejercicio de introspección reflexiva que lleva a la regeneración:

Hay dos caminos para atravesar las fronteras entre Fantasía y el mundo de los hombres: uno acertado y otro erróneo. Cuando los seres de Fantasía se ven arrastrados de esa forma horrible, siguen el camino falso. Sin embargo, cuando las criaturas humanas vienen a nuestro mundo, toman el verdadero. Todos los que estuvieron con nosotros aprendieron algo que sólo aquí podían aprender y que los hizo volver cambiados a su mundo. Se les abrieron los ojos, porque pudieron veros con vuestra verdadera figura. Por eso pudieron ver también su mundo y a sus congéneres con otros ojos. Donde antes sólo habían encontrado lo trivial, descubrieron de pronto secretos y maravillas. Por eso venían de buena gana a Fantasía. Y, cuanto más rico v floreciente se hacía nuestro mundo de esta forma, tanto menos mentiras había en el suyo y tanto más perfecto era también. De la misma forma que nuestros dos mundos pueden destruirse mutuamente, pueden también mutuamente salvarse. (Ende, I999: II9)

En su condición de elegido para rebautizar a la Emperatriz, Bastián se interna en Fantasía y tendrá que aprender a tomar sus propias decisiones. Su iniciación será un camino ascético de autoconocimiento en el que siempre se corre el riesgo de no enfren- 
tarse a la verdad. Xayide, la hechicera que representa el mito de la mujer-tentación, logra convencerlo de que sus amigos son en realidad sus enemigos, y Bastián renuncia a esa amistad hasta que en la soledad de un paraje hostil aprende el valor de la cooperación y de la generosidad que voluntariamente ha perdido. Cuando ante ese reconocimiento sincero sus miedos y complejos desaparecen, cuando sus recuerdos han sido pasto del olvido y ya ha olvidado incluso su nombre, cuando ya sólo es una debilitada imagen del niño real que fue, nuevas y dolorosas reflexiones le harán recuperar esa imagen que denostó. Finalmente, después de que las falsas expectativas fundadas en sus miedos y complejos se hayan derrumbado, después de haber perdido su propio nombre -que es lo más genuinamente personal-, recuperará lo perdido enfrentándose a nuevas pruebas que le harán salir reforzado y le otorgarán la capacidad de enfrentarse al mundo partiendo de su propio conocimiento y aceptación.

\section{5 - Los mitos de la historia interminable}

Como las burbujas en el agua hirviente, de las páginas de este libro surgen los mitos a borbotones. Pero antes de tratar de identificarlos a motu propio nos parece acertado reflexionar sobre lo que el propio autor afirmara (I904: s. p.) acerca de sus fuentes de inspiración:

No oculto que al escribir La historia interminable intenté enlazar con ciertas ideas del romanticismo alemán. No fue por dar marcha atrás, sino porque en dicho movimiento abortado hay semillas que necesitan germinar. Desde Newton nos hallamos cruelmente divididos en dos mundos: el de los objetos, llamado real, y el supuestamente ilusorio del yo. Para no seguir siendo un extraño, el hombre debe aprender de nuevo, como Goethe, a llamar de tú a la Luna. (...) La historia interminable está repleta de alusiones culturales. Y no por falta de imaginación, ya que lo he hecho deliberadamente. En este sentido, el peligro reside no en el universo mental de Bastián, sino en el patrimonio cultural de toda la humanidad. Me he basado en La Odisea, en Rabelais, en Las mil y una noches, en Lewis Carroll y también, aunque en menor medida, en Tolkien, con el que me han comparado los críticos alemanes (ciertamente, los dos debemos mucho a las leyendas célticas de la Tabla Redonda). Me he inspirado en pintores (El Bosco, Goya, Dalí), en el antroposofismo y en el budismo zen. La cábala, que da un sentido metafísico a los diferentes sonidos, me sirvió de guía a la hora de elegir los nombres de los personajes. 
Como el escritor mantiene, las evocaciones a El señor de los Anillos y Alicia en el País de las Maravillas son evidentes: con el primero se asemeja en la noción del portador de un tesoro, pues tal y como Frodo portaba el anillo en la obra tolkiana, Atreyu lleva a Auryn. Con el segundo, en el viaje interior y fantástico: así como Alicia penetra en un mundo surrealista, Bastián entra en Fantasía. Creemos encontrar a Rabelais, en la frase inscripta en Auryn ( "haz lo que quieras"), expuesta de igual forma en Gargantúa y Pantagruel: "fayçe que vouldras". Evocamos La Odisea en la expresión "Soy Nadie" y en la hechicera Xayide, y reconocemos El Jardín de las Delicias de El Bosco en la onírica descripción de la Ciudad de los Antiguos Emperadores.

Pero aún hay más, porque podemos también entrever la presencia de La Divina Comedia y sus tres grandes estructuras: el infierno, el purgatorio y el cielo. Y el recorrido de Bastián se puede emparentar con el de Dante: así como el viaje de la mano de Virgilio se inicia con la constatación de una vida carente de sentido, en La Historia Interminable la aventura se inicia con el reconocimiento que el protagonista hace sobre su propia nulidad personal.

Entre líneas evocamos, igualmente, al Friedrich Nietzsche de Así habló Zaratustra: el león - una de las tres entidades de la tríada camello/león/niño- quiere ser el señor de su propio desierto y conquistar la libertad que llegará cuando sea capaz de crear nuevos valores. En la historia de Ende también encontramos una fiera similar, Gmork, que personifica la amenaza destructora de la Nada y que reconoce, en un rapto de autoconmiseración, el deleznable objetivo de la misión que le ha sido encargada.

Es fácilmente identificable el Ouroboros, concepto que, tomando la forma de dragón o serpiente encerrada sobre sí misma al morderse su propia cola, representa la naturaleza cíclica de las cosas y el eterno retorno (también evocado por Nietzsche), y sugiere que el final de un camino o de un proceso significa un nuevo principio. Este mito, más genéricamente, también encierra las ideas de movimiento, continuidad, autofecundación, la infinitud del tiempo y la continuidad de la vida. Apareció por primera vez en Egipto, tanto en los sarcófagos del Imperio Nuevo como en el Libro de los Muertos, y en la Grecia clásica indicando el curso cósmico en un tiempo infinito; como símbolo de la eternidad fue adoptado también por la mitología nórdica, la alquimia, la francmasonería y el arte sepulcral cristiano.

Finalmente, apreciamos cómo en la novela de Ende resucitan Pegaso, el Ave Fenix, el centauro Quirón, el Oráculo de Delfos, Shahriar y Scheherezade de Las mily una noches, y Shakespeare (Chsespirk, el narrador de leyendas). 
Pero más allá de esas evidencias intertextuales ${ }^{6}$, abundaremos en la hermenéutica del texto para identificar en esa abundante simbología del mundo clásico unos cimientos contextuales que se apoyan en la psicología analítica de Karl Gustav Jung, cuyas teorías sostienen que en la génesis del discurso fantástico se articulan los contenidos del inconsciente colectivo, lo que contribuye a que el ser humano alcance su proceso de individuación. Y a partir de estas aportaciones no podemos renunciar a estudiar las similitudes de los héroes Bastián y Atreyu con la cosmogonía del héroe transcultural que Campbell describe en su obra El héroe de las mil caras.

\section{6 - Bastián-Atreyu o las mil caras del héroe mítico}

La rotundidad con que Campbell (ı989: ıo) nos habla de la génesis heroica nos retrotrae al tiempo primigenio e ignoto donde el héroe, en una suerte de palingenesia recurrente en todas las culturas, se regenera y renace cíclicamente hasta desembocar en el tiempo presente: "En todo el mundo habitado, en todos los tiempos y en todas las circunstancias, han florecido los mitos del hombre; han sido la inspiración viva de todo lo que haya podido surgir de las actividades del cuerpo y de la mente humanos". En efecto, tanto el Gilgamesh sumerio -aquella primera epopeya mítica del hombre que intenta superarse a sí mismo, emprendiendo un camino en el que aprehenderá que el verdadero sentido de la vida no es la inmortalidad, sino el hecho de recorrerlo junto a otros en los que se verá complementado-, como el héroe más futurista-así se nos antoja, por ejemplo, el sensible replicante de Blade Runner-no son sino la alegoría de una inspiración humana y una aspiración a que la vida tenga sentido.

Afirma después que "el héroe inicia su aventura desde el mundo de todos los días hacia una región de prodigios sobrenaturales, se enfrenta con fuerzas fabulosas y gana una victoria decisiva" (Campbell, I989: 25). Y esto es, precisamente, lo que le ocurre a Bastián y a su alter ego, Atreyu. Pues diríase que ambos son una misma persona: uno pertenece al mundo de los hombres y otro a Fantasía, pero son dos caras de la misma moneda del héroe mítico, dos opuestos complementarios que conforman una divinidad creadora en la que otros opuestos, el conflicto y la reconciliación posterior, permiten el flujo de fuerzas creadoras del mundo y del hombre. Esta percepción de héroe coincide con la de Campbell (ı989: 28), que además sostiene que "El camino común de la aventura mitológica del héroe es la magnificación de la fórmula representada en los ritos de iniciación: separación-iniciación-retorno [...]. El héroe inicia su aventura desde el mundo de todos

\footnotetext{
${ }^{6}$ En la obra de Ende se evidencia como en pocas aquella definición de intertextualidad que germinara en la teoría literaria de Mijail Bajtín (I989): una polifonía textual donde establece relaciones dialógicas esenciales con ideas ajenas; o como anteriormente concluyera Kristeva (I98I: I9O): "todo texto es la transformación o absorción de otro texto".
} 
los días hacia una región de prodigios sobrenaturales, se enfrenta con fuerzas fabulosas y gana una victoria decisiva." Y ello porque toda iniciación supone una separación, un desapego emocional que será lo que facilite al aventurero la posibilidad de encontrarse o reencontrarse consigo mismo

Compararemos, por tanto, las etapas clásicas de la aventura universal con las peripecias por las que atraviesan los héroes de Ende, en un nuevo intento de entender, como dice Campbell (ı989: 28), "no sólo el significado de las imágenes vigentes en la vida contemporánea, sino la unicidad del espíritu humano en sus aspiraciones, poderes, vicisitudes y sabiduría."

\section{La partida}

\section{a) La llamada de la aventura}

Según Campbell (ı89), antes de iniciar la aventura, aparece un heraldo que invita a la partida. Suele tratarse de un ser repulsivo, oscuro o terrorífico, porque es la representación de la profundidad inconsciente donde se acumulan los elementos de la existencia que han sido rechazados o ignorados.

En este primer estadio el destino llama al héroe hacia una zona desconocida que, aún cuando puede adquirir varias formas, "siempre es un lugar de fluidos extraños y seres polimorfos, tormentos inimaginables, hechos sobrehumanos y deleites imposibles" (Campbell, r989: 40).

Recordemos que un mensajero va a la búsqueda de Atreyu, que hasta entonces vivía del modo más "normal” en que se puede vivir en Fantasía, y que Bastián escucha esa llamada a la aventura al sumergirse en la narración. Para éste último, lo que en principio es una leve sospecha acaba convirtiéndose, en el transcurso de la lectura que hace del libro, en una inaudita evidencia que se manifiesta en la voz invitadora de Atreyu. Y entonces, "grande o pequeña, sin que tenga importancia el estado o el grado de la vida, la llamada levanta siempre el velo que cubre un misterio de transfiguración; un rito, un momento, un paso espiritual que cuando se complementa es el equivalente de una muerte y de un renacimiento" (Campbell, I989: 37). Veremos el sinuoso camino de esa transfiguración en las siguientes etapas.

\section{b) La negativa al llamado}

A menudo, tanto en la vida real como en los cuentos, la llamada no es atendida, 
circunstancia que convierte la aventura en una negación cuya inmediata consecuencia es que, debido a la pérdida de poder, el individuo se convierte en una víctima que ha de ser salvada.

Bastián, al principio, rehúsa esa llamada, duda sobre si los personajes del libro se están refiriendo a él y la acepta una vez que constata en los párrafos del mismo su propia historia. Al aceptar la aventura, estará a salvo de las burlas y escarnios de sus compañeros de colegio y de la melancólica indiferencia de su padre.

\section{c) Ayuda sobrenatural}

Cuando el héroe acepta la llamada, su primer encuentro suele ser con una figura protectora que le ofrece un amuleto con el que combatir al mal. "La fuerza protectora está siempre presente dentro del santuario del corazón y existe en forma inmanente dentro o detrás de las extrañas apariencias del mundo" (Campbell, r989:47). La valiente respuesta a la llamada se premia con la posesión de las fuerzas del inconsciente, que simbólicamente evidencia que la Madre Naturaleza también apoya tan poderosa empresa.

Auryn es el amuleto que portan nuestros héroes y, tal como lo describe Campbell (I989: 47), será “protector y peligroso, maternal y paternal al mismo tiempo". Efectivamente, supondrá simultáneamente protección y amenaza porque cada deseo satisfecho por el Auryn implica en Bastián el paulatino olvido de sus recuerdos terrenales, con la consiguiente dificultad para hallar el camino de regreso. Por eso Atreyu le advierte: "la Alhaja te da el camino pero, al mismo tiempo, te quita la meta” (Ende, I999: 194).

\section{d) El cruce del primer umbral}

Continúa Campbell advirtiendo cómo el héroe, ayudado por la personificación de su destino, avanza hasta llegar al "guardián del umbral" que custodia la entrada a la zona desconocida. Tras él aguarda el peligro, la oscuridad, el enfrentamiento con lo desconocido, que es la proyección de los contenidos inconscientes.

Las tres puertas mágicas que atraviesa Atreyu son ese umbral, y las esfinges de mirada petrificante, sus guardianes.

\section{e) Elvientre de la ballena}

El paso por el umbral mágico es un tránsito a una esfera de renacimiento que queda simbolizada en la imagen mundial del vientre de una ballena, en clara alusión bíblica 
al episodio vivido por Jonás. Es el templo interior o los confines del mundo, y por eso sus puertas están custodiadas por guardianes que disuaden al incapaz de seguir adelante.

Y, en este sentido, mantiene el investigador: “Alegóricamente, pues, la entrada al templo y la zambullida del héroe en la boca de la ballena son aventuras idénticas; ambas denotan, en lenguaje pictórico, el acto que es el centro de la vida, el acto que es la renovación de la vida". Y una nueva simbiosis - añadimos nosotros- con la Naturaleza, porque ese germinal receptáculo también recuerda al útero materno, al huevo creador de vida, al capullo que metamorfosea el gusano en crisálida.

\section{La iniciación}

\section{a) Elcamino de las pruebas.}

Para Campbell (1989: 63), ésta es la fase favorita de la aventura mítica y la que ha generado más literatura. Como en nuestros sueños, en los que "encontramos todavía los eternos peligros, las quimeras, las pruebas, los ayudantes secretos y las figuras instructoras, y en sus formas podemos ver reflejado no sólo el cuadro de nuestro presente caso sino también la clave de lo que debemos hacer para salvarnos”, así el héroe es ayudado por otras entidades a superar esas pruebas.

Ni qué decir tiene que en La Historia Interminable se cumple también este pronóstico y se constituye en la trama y la urdimbre del simbólico tapiz que conforma el relato.

\section{b) El encuentro con la diosa}

La figura mitológica de la Madre Universal aparece como una presencia nutritiva y protectora.

La mujer, en el lenguaje gráfico de la mitología, representa la totalidad de lo que puede conocerse. El héroe es el que llega a conocerlo. Mientras progresa en la lenta iniciación que es la vida, la forma de la diosa adopta para él una serie de transformaciones; nunca puede ser mayor que él mismo, pero siempre puede prometer más de lo que él es capaz de comprender. Ella lo atrae, lo guía, lo incita a romper sus trabas. Y si él puede emparejar su significado, los dos, el conocedor y el conocido, serán libertados de toda limitación. (Campbell, I989: 7I).

La Emperatriz Infantil es la personificación de esa diosa, el arquetipo de la Diosa Madre que otorga la vida, permanencia y muerte a los seres de Fantasía. Tanto Atreyu como Bastián dialogan con la diosa, aprenden con su sabiduría innata, en algún momento de su aventura. 


\section{c) La mujer como tentación}

Como ya ocurriera en La Iliada y La Odisea, también existe la posibilidad de ver a la mujer como sujeto de tentación. En el caso de Bastián también habrá una fémina tentadora: Xayide, la hechicera que cuestionará los principios del "Salvador de Fantasía” y tratará de convencerlo para que desconfíe de sus amigos y se convierta en el sucesor de la Emperatriz Infantil.

\section{d) La gracia última.}

Campbell (ı989: IIо) considera que "moverse hacia el destino es como la eternidad. Reconocer la eternidad es la iluminación y no reconocerla trae el desorden y el mal. El conocimiento de la eternidad hace al hombre comprensivo y la comprensión amplía su mente; la amplitud de visión trae nobleza y la nobleza es como el cielo".

Bastián aprende esta lección cuando conoce la Ciudad de los Antiguos Emperadores, el lugar al que llegaban los humanos que habían perdido todos los recuerdos de su mundo o aquellos a los que el ansia de poder los había consumido.

\section{El regreso}

\section{a) La negativa al regreso.}

Llegando ya a las postrimerías de la aventura, “cuando la misión del héroe se ha llevado a cabo, [...] el aventurero debe regresar con su trofeo trasmutador de la vida". (Campbell, r989: пз3)

Mas si el héroe queda deslumbrado por el mundo en que transcurre su aventura, será reticente a volver a su mundo de origen. Esto mismo le ocurre a Bastián, porque intuye que el poder y el respeto de los que goza en Fantasía desaparecerán si vuelve a su vida cotidiana.

\section{b) El rescate del mundo exterior}

Pero el héroe ha de volver a su mundo de origen, pues sin la vuelta, la aventura carecería de sentido. Entonces, "ya sea rescatado desde el mundo exterior o impulsado por el mundo inferior, o dirigido gentilmente por las divinidades guías, el elegido tiene que volver a entrar con su don a la hace tiempo olvidada atmósfera de los hombres que son fracciones e imaginan ser completos" (Campbell, ı989: г26). 
Y he aquí la clave de cómo Bastián se prepara para el regreso: La Mina de las Imágenes le ayudará a encontrar un deseo auténtico y profundo, y Atreyu, con su abnegada amistad, le dará el impulso definitivo para volver a su mundo originario con las alforjas repletas de lo aprendido en Fantasía.

\section{c) Elcruce del umbral del regreso}

Para Campbell, los dos mundos, el real y el imaginario, son tan complementarios como la vida y la muerte o el día y la noche. El segundo es una dimensión olvidada del mundo real y su exploración da sentido a la hazaña del héroe. Sin embargo:

El primer problema del héroe que regresa es aceptar como reales, después de la experiencia de la visión de plenitud que satisface el alma, las congojas y los júbilos pasajeros, las banalidades y las ruidosas obscenidades de la vida. ¿Por qué volver a entrar a un mundo así? ¿Por qué intentar hacer plausible, o por lo menos interesante la experiencia de la felicidad trascendental a hombres y mujeres consumidos por las pasiones? (Campbell, r989: г27).

El héroe vuelve a su mundo primigenio imbuido de nuevas miras, y ahora ha de enseñar esa nueva visión que trae en su interior. Por eso Atreyu le decía a Bastián que deberá enfrentarse a la sociedad con el elixir que destroza los egos, redime la vida y permite luchar contra la Nada que nos acosa y devora por momentos. A nuestro juicio, aunque Ende afirme no pretenderlo, ésta es la parte más didáctica del libro, pues contiene una profunda enseñanza metafísica.

\section{d) La posesión de los dos mundos y libertad para vivir}

El resultado de la singladura vivida por el héroe será la meta del mito: “despejar la necesidad de esa ignorancia de la vida efectuando una reconciliación de la conciencia del individuo con la voluntad universal. Y esto se efectúa a través de una valoración de la verdadera relación entre los fenómenos pasajeros del tiempo con la vida imperecedera que vive y muere en todos” (Campbell, I989: I36). Aquí es nítida la evocación al Eterno Retorno nietzcheano en el que todo va y todo vuelve, aunque Campbell le otorgue una perspectiva más en consonancia con aquel río de Heráclito que nunca lleva el mismo agua: "como en la experiencia real de cada ser vivo, así sucede todo en la figura grandiosa del universo vivo: en el abismo del sueño las energías se refrescan y en el trabajo del día se agotan; la vida del universo se gasta y debe ser renovada”. Sin entrar en que esa corriente vital fluya en circuito cerrado o en simbólico cauce fluvial, sus aguas regarán, indudablemente, los áridos páramos de la psique aletargada. 
Ser héroe, por tanto, no sólo es vivir una aventura sin más, sino que conlleva la manifestación del inconsciente personal y colectivo en su forma de comprender el mundo, motivo por el cual "el ciclo cosmogónico [...] ha de seguir adelante no por medio de los dioses, que se han vuelto invisibles, sino por los héroes de carácter más o menos humano y por medio de los cuales se realiza el destino del mundo" (Campbell, r989: I77).

El ciclo de Bastián, en definitiva, será la transformación del héroe, el encuentro con esa presencia que le hará reconciliarse con su destino y, precisamente, ahí encontraremos el significado último de la historia: un viaje iniciático para reencontrarse y encontrar la capacidad de amar que, al fin y a la postre, es el significado último de La Historia Interminable.

\section{7 - Y a modo de conclusión: "para vivirlo hay que leerlo"}

El autor crea sinergias entre lector e historia desde el primer momento, cuando afirma:

Quien no haya pasado nunca tardes enteras delante de un libro, con las orejas ardiéndole y el pelo caído por la cara, leyendo y leyendo, olvidado del mundo y sin darse cuenta de que tenía hambre o se estaba quedando helado... Quien nunca haya leído en secreto a la luz de una linterna, bajo la manta, porque Papá o Mamá o alguna otra persona solícita le ha apagado la luz con el argumento bienintencionado de que tiene que dormir, porque mañana hay que levantarse tempranito... Quien nunca haya llorado abierta o disimuladamente lágrimas amargas, porque una historia maravillosa acababa y había que decir adiós a personajes con los que había corrido tantas aventuras, a los que quería y admiraba, por los que había temido y rezado, sin cuya compañía la vida le parecería vacía y sin sentido... Quien no conozca todo eso por propia experiencia, no podrá comprender probablemente lo que Bastián hizo entonces. (Ende, I999: Io)

Porque más allá de la atractiva invitación que se nos hace a la inmersión fantástica, el fragmento precedente es el testimonio supremo de que La Historia Interminable, a fin de cuentas, constituye una magnífica propuesta de invitación a la lectura y a indagar en la naturaleza del fenómeno literario. El momento "casi solemne" de apertura del libro es un acto inherente a la pasión lectora, y quienes tenemos la fortuna de disfrutarlo en su significado más rotundo, alguna vez hemos experimentado la misma duda metafísica de Bastián:

Me gustaría saber», se dijo, «qué pasa realmente en un libro cuando está cerrado. Naturalmente, dentro hay sólo letras impresas sobre el papel, pero sin embargo... Algo debe de pasar, porque 
cuando lo abro aparece de pronto una historia entera. Dentro hay personas que no conozco todavía, y todas las aventuras, hazañas y peleas posibles... y a veces se producen tormentas en el mar o se llega a países o ciudades exóticos. Todo eso está en el libró de algún modo. Para vivirlo hay que leerlo, eso está claro. Pero está dentro ya antes. Me gustaría saber de qué modo. (Ende, I999: I4)

Esa duda tan infantilmente adulta resume en tres sencillas palabras el epítome del acto lector: leer para vivirlo. Para vivir y disfrutar, en toda su plenitud, la vasta odisea de la condición humana. 


\section{Referencias}

- Bajtín, M. (I989). Teoría y estética de la novela. Madrid: Taurus.

- Bettelheim, B. (1977). Psicoanálisis de los cuentos de hadas. Barcelona: Crítica.

- Borges, J. L. (1998). Otras inquisiciones. Madrid: Alianza.

- Campbell, J. (1972). El héroe de las mil caras. 8ª reimp. México: FCE.

-Ende, M. La realidad de la fantasía. Artículo de Jean Louis de Ramboures para El País, 22-4-I984. Obtenido el i6 de Junio de 2012 desde: http://elpais.com/diario/r984/O4/22/ cultura/45I432804_8502I5.html

- Ende, M. (r996). Pensamientos de un indígena centroeuropeo, Carpeta de apuntes. Obtenido el I5 de Junio de 2012 desde: http://ende.blogcindario.com/2009/o4/oor33-pensamientos-de-un-indigena-centroeuropeo.html

- Ende, M. (I996). Sobre el eterno infantil, Carpeta de apuntes. Obtenido el I5 de junio de 2OI2 desde:

http://ende.blogcindario.com/2OIO/II/Oo286-sobre-el-eterno-infantil.html

-Ende, M. (1999). La historia interminable. Madrid: Alfaguara.

- Freud, S. (г900). La interpretación de los sueños, en S. Freud (I948,I), (pp. 231-58г). Madrid: Biblioteca Nueva.

•Jung, C.G. (I964). Recuerdos, sueños, pensamientos. Barcelona: Seix Barral.

- Kristeva, J. (I98I). Semiótica. Madrid: Fundamentos.

- Nietzsche, F. (1999). Así habló Zaratustra. Madrid: Edimat Libros.

- Pereda, R. M. (1982). La imaginación cambia la conciencia del lector. El País, 9 de Junio de r982.

- Pérez Valverde, C. (2002). La Edad de Oro de la Literatura Infantil. Didáctica de la Literatura en Lengua Inglesa. Granada: Grupo Editorial Universitario.

- Pérez Valverde, C. (2Оіо). Construcción de identidades femeninas en la ficción infantil: de raíces antropológicas y estudios culturales. En C. Vázquez, (Ed). Diálogos intertextuales z: En busca de la vozfemenina (pp. 297-3o9). Frankfurt: Peter Lang. 